Kok M., H. Massinen, I. Moshnikov, E. Penttilä, S. Tavi \& L. Tuomainen (toim.) 2019. Pidetään kielet elävinä - Keeping languages alive - Piemmö kielet elävinny. AFinLAn vuosikirja 2019. Suomen soveltavan kielitieteen yhdistyksen julkaisuja n:o 77. Jyväskylä. s. 1-18.

\title{
Tove Bull
}

UiT - the Arctic University of Norway

\section{The two Norwegian official written standards, bokmål and nynorsk. Linguistic and ideological implications of national bilingualism and biliteracy}

The long-lasting Norwegian history of official biliteracy with two equal written standards has attracted the interest of many scholars, both nationally and internationally. The present paper gives an overview of the historical development more or less similar to what is found in most Norwegian language histories, though with a different perspective. The paper discusses and seeks to answer the following questions: What was the ultimate aim of the language planners in the new independent nation state of Norway after 1814? Did they reach this aim? If not, what was achieved instead?

The historical development of bokmål and nynorsk is explained as well as the presentday linguistic situation in Norway. Practical samples of both language forms are given, and language reforms, which have been important to both written standards, are discussed in chronological order.

Keywords: language planning, biliteracy, language ideology, nationalism Asiasanat: kielensuunnittelu, kahden kirjakielen järjestelmä, kieli-ideologia, nationalismi 


\section{Introduction ${ }^{1}$}

Research on modern Norwegian language history and language planning has been on the agenda of language historians and sociolinguists for more than a hundred years, and the scholarly literature is comprehensive (e.g. Indrebø 1951; Haugen 1966; Skard 1976; Torp \& Vikør 2003; Hyvik 2009; Bull 2011, 2018; Nesse 2018; Hoel 2018; Nesse \& Torp 2018). It should be mentioned that for the first time in history, Norway has a comprehensive and up to date language history in four volumes, Norsk språkhistorie I-IV (Sandøy \& Nesse 2016-2018). Most relevant for our present purposes would be volumes III Ideologi (Bull 2018) and IV Tidslinjer (Nesse 2018). These volumes may however be difficult to access for a Finnish reader who wishes more background information. For these purposes, Bandle et al. $(2002,2004)$ can be recommended instead, especially chapters on Norway in the $19^{\text {th }}$ and $20^{\text {th }}$ century.

The present paper has its focus on the long-lasting Norwegian language planning endeavour. Sociolinguists or more specifically language historians do not necessarily agree as to when this endeavour started or when it ended, or even if it ever has ended. I will, however, tell the story, i.e. my interpretation of the historical development, with a starting point in 1814 and up to the present time. I call it a language planning endeavour, for good reasons. In addition to the historical review I will also elaborate on the following questions: What was the ultimate aim of the language planners? Did they reach this aim? If not, what was achieved instead? I argue that it is justified to call the long lasting Norwegian official language planning an endeavour because - as we soon are about to see - what was planned was not necessarily accomplished, and what was accomplished was not planned. To my knowledge, these questions have never been discussed explicitly in a scholarly context before.

Thus, my paper partly consists of a chronological narrative about the origin and development of what gradually became the still existing Norwegian national bilingualism or more precisely, national biliteracy. ${ }^{2}$ As an integrative part, I also attempt to analyse and explain the described development.

1 This paper is based on a plenary at the AFinLA Autumn Symposium in Joensuu in November 2018. The aim of my plenary was to introduce the Finnish audience to modern Norwegian language history and language planning.

Of course, bilingualism and biliteracy are not synonym concepts. However, in Norwegian language histories, it is not uncommon to use the terms synonymously. Given that this paper only focuses on written languages I prefer to use 'biliteracy', except when I refer to official language policy and the discussion about whether Norway has one or two Norwegian languages. 


\section{The historical background}

As a starting point of our narrative I will take the year 1814, when Norway, due to the outcome of the Napoleonic wars, gained independence from Denmark after having been what could be called a (semi-)colony for 400 years. The status of the relationship between Denmark and Norway during these centuries, has been ardently discussed by historians for almost 200 years (e.g. Dyrvik 1998: 14ff.; Rian 1997). Nonetheless, there is still no consensus on this issue. The different characteristics or names commonly used about the period might suggest some of the different view-points; dansketida - 'the Danish time' or 'the Danish period, personalunionen - 'the personal union', pointing to the fact that we had a common king, tvillingriket - 'the twin kingdom' or 'the twin realm', and from a totally different angle: firehundrearsnatta 'the 400 years' night'.

From 1814 to 1905 the country was in union with Sweden, in this period with more autonomy than in the union with Denmark, with our own Parliament and from May 17, 1814 also a Norwegian constitution. From a linguistic point of view, the union with Sweden did not represent any important changes (Torp \& Vikør 2003:140; Bull 2015; Hoel 2018b: 446f.).

Relatively early in the Danish period, i.e. during the early 1500 s, Old Norse, the written language of Norway in the medieval times, was completely replaced by Danish while the oral language survived in a multitude of dialects (Torp \& Vikør 2003; Nesse \& Torp 2018). These dialects, however, underwent major linguistic changes from the 1300 s onwards. From a sociolinguistic point of view, the manner in which the replacement of Old Norse took place is in itself interesting; it started at the top of society, in the king's court and among the social elite, and gradually Danish conquered more and more linguistic domains, until a total language shift had taken place (Indrebø 1951: 219-330). Such a domain loss over about 100 years might remind us of the loss of linguistic domains to English that we experience nowadays. The domain loss to Danish was, however, much more widespread, given that written Danish replaced written Norwegian completely (Torp \& Vikør 2003; Nesse \& Torp 2018).

The situation remained unchanged for 400 years. The Bible was not translated into Norwegian until the twentieth century. All primary education was in Danish. Even after the dissolution of the union in 1814, throughout the nineteenth century and into the early twentieth century, Danish was the written language of Norway. However, from the 1830s onwards, some revitalizing linguistic work, mostly in the form of language policy discussions, pointed towards what was to come in the future. These were initiatives, not from the political authorities, but from private persons who wanted to replace the written Danish idiom with some variety that could be called Norwegian (Torp \& Vikør 2003; Bull 2011: 433; Hoel 2018). 
Danish and Norwegian are mutually intelligible languages. That, of course, explains why it was possible to keep Danish as the official written language in Norway for almost a hundred years after the union was dissolved. The Danish language was even called "Norwegian" in the revised version of the constitution of November 2014, and also in other documents, both official and non-official (Bull 2015).

\section{The nineteenth century - Nationalism/National romanticism}

During the first half of the nineteenth century, there were, in fact, no official language planning initiatives, and certainly no official language planning strategies. If it had not been for the strong interest that the so-called language question raised among mostly nationally-oriented people in the civil society ${ }^{3}$ (almost only men) we might still have shared the written language with the Danes. This was during the national romantic period, and as we know, the underlying linguistic ideology of that time was based on strong sentiments about deep-rooted links between the nation state and one national language. As it were, any nation proved itself to be an independent nation-state through its national language. Against that background, from the 1930s onwards, the agenda was set for the language question, and the issue of replacing Danish with "Norwegian" (which was by no means a clear concept at that time) was under constant discussion among those we now would call the intellectuals in the country.

\section{$4 \quad$ Two different language planning approaches}

From the middle of the nineteenth century, two different language planning approaches were under development, from the beginning independent of one another, but later in competition with each other. One was initiated by Ivar Aasen (1813-1896), a self-taught man from the western part of the country, who coined what he called Landsmaal ('the language of the country'), the predecessor of Nynorsk, the other by Knud Knudsen (1812-1895), an Oslo teacher originally from the southern part of the country (Gimnes 2002: 464-466). Ideologically, their ideas of what kind of basis a standard language should be built on were very different. Knudsen's ideas were rather conventional. In line with standardization ideologies in other European countries, he argued that a written standard should be built

3 I use the term "civil society" in the way Jürgen Habermas has used it in many publications, among others his doctoral dissertation (Habermas 1962). 
on the oral language of the educated elite in the towns in south-eastern Norway, particularly the capital. This educated elite spoke a variety that to a high degree was Norwegianised pronunciation of written Danish. Many of the speakers had their family background in Denmark. In terms of practical language planning, Knudsen proposed a gradual approach where Danish linguistic elements, such as grammar and vocabulary, would be replaced by corresponding Norwegian ones. This is the ideological background of our bokmål ('book language') variety which during Knudsen's time was called riksmål ('the language of the realm/country'), or dansknorsk ('Danish-Norwegian') (Gimnes 2002: 465-466; Bull 2011: 433-434). Though Knudsen's thoughts about what kind of basis a standard language should be built upon were rather conventional, it should be mentioned that his gradualist approach was very innovative (e.g. Hoel 2018: 458-481; Johnsen 2005). As far as I know, a similar approach - the way in which Danish or Danish-Norwegian gradually was Norwegianised over time - has never been tried anywhere else.

Ivar Aasen, who from the 1840s financed his activities through stipends and scholarships, had an approach more or less opposite to Knudsen. He wanted to build the written standard on Norwegian dialects. Thus, the basis of the standard should be the language spoken by a Norwegian peasant, as Aasen expressed it. He travelled through the country to study Norwegian dialects. On the basis of his extensive fieldwork he wrote both grammars and dictionaries, first a descriptive grammar (1848) and dictionary (1850) with data from different dialects, and some years later, normative ones (1864, grammar; 1873, dictionary) (e.g. Hoel 2018: 481-490; Venås 1996). These two different standardisation ideologies have been with us since they were launched in the middle of the nineteenth century until this very day.

Thus, both Aasen and Knudsen did much more than launch ideas about a potential Norwegian written language; both of them worked hard and systematically - though in different ways - to lay the basis of a new standard language. In 1862, one of Knudsens proposals for a more simplified orthography actually resulted in an initiative from the Ministry of Church and Education to issue the very first spelling reform, which got rid of double vowels to mark vowel length; Miil was to be written Mil, Huus Hus, etc. Imported words got a more simplified spelling as well, Filosof replaced Philosoph, for instance. In fact, this very small and restricted, more or less cosmetic reform represents the only example of official corpus planning in the $19^{\text {th }}$ century (Torp \& Vikør 2003: 125).

\section{$5 \quad$ Status planning versus corpus planning}

On the other hand, there were several examples of status planning before 1900 . Discussions about the need for a separate Norwegian language, about what the new norm should look like, what linguistic basis it should have, etc., took place within the 
civil society first and much later through governmental initiatives. At the same time, the concrete and practical endeavours by Aasen and Knudsen to create a norm or a standard based on their different ideologies were developing. And then, in 1885, a majority of members of Parliament voted for a proposal to give equal status to what they called norsk Folkesprog - 'the Norwegian Folk Language'- with what they called det almindelige Skrift-og Bogsprog -'the common written and book language - as school and public language. This was indeed a very radical step. In hindsight one might wonder whether the parliamentarians really understood what they voted for. Those who voted for the proposal, apparently wanted to replace Danish with a "Norwegian" language, or at least pave the way for school and official use of a "Norwegian" language. Based on this majority decision, it is fair to say that 1885 is the fundament and marks the starting point of the history of Norwegian bilingualism/ biliteracy. Though language historians have over time disagreed on the meaning of the two concepts (Norsk Folkesprog and det almindelige Skrift-og Bogsprog) (Elgvin 1969a, 1969b; Bull 1987; Jahr \& Schanche 1988; Vikør 2018), there is no reason to doubt that the concept 'the Norwegian Folk-Language' refers to Aasens Landsmaal and det almindelige Skrift- og Bogsprog to Danish or Danish-Norwegian (given the 1862 reform).

For several reasons, the resolution passed by Parliament was daring and radical, not least because neither Aasen's Landsmaal nor Knudsen's revision of Danish had at that time reached the stage of being fully developed standards, though Aasen himself had written grammars and dictionaries and also some model texts. In addition, he wrote poetry where he applied the new written idiom. Some of his supporters started quite early to write in Landsmaal; most importantly, the author Aasmund Olavsson Vinje wrote and published within different genres in the weekly magazine Dølen between 1858 and 1870 (Gimnes 2002: 464-465). A publishing company, Det Norske Samlaget, was established in 1868, translations of Bible books were under way, hymns were written by a professor of theology, Elias Blix, who actually was the Minister of Church and Education in 1885 and thus responsible for implementing the Parliamentary resolution in the school system. Blix was also a very strong adherent of Aasen's Landsmaal. In that sense, in 1885, the Landsmaal was much further developed as a standard written language than Knudsen's revision of Danish. In fact, in 1885, Knudsen's variety was far away from being anything like a standard language. Nevertheless, in 1887 the ministry decided that school children should be allowed to include some of Knudsen's reform proposals in their writing of Danish (Hoel 2018: 491), though these proposals had no formal status at that time.

The decision in 1885 was followed by revisions of the school laws in 1892. The municipalities were given the right to decide which variety should be used in schools, Danish (often called Danish-Norwegian) or Landsmaal. Rules on how to decide on this were also given. Through these decisions the biliteracy situation of Norway had 
become a public political responsibility and was thus formally consolidated (Hoel 2018: 430, 494, 508).

\section{Bokmål, nynorsk, samnorsk}

Over the years, Aasen's and Knudsen's approaches were gradually codified into two different standard written varieties, both called Norwegian. The official names of the two standards became Nynorsk and Bokmål in 1929. So, how did Norway cope with the fact that not only one, but two standard languages had been developed as an answer to the long-felt need of establishing an official language different from Danish? It did not take long before the biliteracy situation was looked upon as a challenge, and far from ideal. Already in the 1880s some of those who set the tone in the public sphere launched the idea to develop what was named Samnorsk, common Norwegian. The author Arne Garborg (1851-1924) was the first to use the term in 1877 (Bull 2011: 435-436). In 1909, professor Moltke Moe (1859-1913) reintroduced the term in an article; he was for a long time wrongly considered the creator of the term. Thus, gradually, an idea was developed to merge the two languages into one single standard by the help of language planning, i.e. corpus planning. The thought was that this common Norwegian standard should develop harmoniously through a gradual process, where the two standards finally through relatively frequent language reforms should merge into one written Norwegian language (Bull 2011: 435-438). As far as I have been able to find out, at this early stage (the beginning of the $20^{\text {th }}$ century), no one argued explicitly in favour of a linguistic situation of written bilingualism, that is, for maintaining the existing situation. Somehow, it seems that the situation was looked upon more as a result of accidental circumstances than as an accomplishment that was planned for. The original plan had been to replace the Danish language in Norway by one Norwegian standard. Instead, the new independent nation state had ended up with two standards. Because of this, a new language planning strategy was developed; the idea was that a gradual process of corpus planning within the two standards should over time bring them together into a joint Norwegian language, Samnorsk. To start with, this was never explicitly mentioned in the mandate of the committees which were appointed to prepare the so-called language reforms (also called spelling reforms, see Bull 2011: 434-436). Actually, the very first reforms were exclusive in the sense that they applied to only one of the standards. 


\section{$7 \quad$ Language reforms}

In Table 1 some basic information on the language reforms is provided. The years from 1901 onwards refer to the years when the reforms were formally agreed upon by Parliament while "characterizing aspects" refer to the underlying ideology, main achievements or other typical features that characterizes the reform in particular.

TABLE 1. Language reforms in Norway 1862-2012.

\begin{tabular}{|l|l|l|}
\hline Year & Standard under revision & Characterizing aspects \\
\hline 1862 & $\begin{array}{l}\text { adjustment of the Danish } \\
\text { orthography used in Norway }\end{array}$ & a minor, more or less "cosmetic" reform \\
\hline 1901 & nynorsk only & $\begin{array}{l}\text { Resulted in two different nynorsk standards; one } \\
\text { of them did not last long, and seems not to have } \\
\text { been officially accepted. }\end{array}$ \\
\hline 1907 & bokmål only & The standard can no longer be considered Danish. \\
\hline 1910 & nynorsk only & a minor reform \\
\hline 1917 & both standards & samnorsk ideology \\
\hline 1938 & both standards & samnorsk ideology \\
\hline 1959 & both standards & $\begin{array}{l}\text { samnorsk ideology, læreboknormalen'the school- } \\
\text { book-norm' }\end{array}$ \\
\hline 1981 & bokmål only & Samnorsk forms were removed from the standard. \\
\hline 2005 & bokmål only & $\begin{array}{l}\text { Further removals of Samnorsk forms and so-called } \\
\text { less-used forms }\end{array}$ \\
\hline 2012 & nynorsk only & $\begin{array}{l}\text { No Samnorsk ideology; conservative and “less- } \\
\text { used” forms removed from the standard }\end{array}$ \\
\hline
\end{tabular}

All the reforms - except for the small adjustments in 1862 - were prepared by a committee consisting of university professors, teachers, authors and other linguistically competent members, elected by the ministry responsible for language matters and education (Bull 2011: 435). The committee members were adherents of either bokmål or nynorsk, and when both standards were under revision at the same time, the numbers of the members being in favour of either bokmål or nynorsk were always balanced.

When we look at the years when a new reform was agreed upon by Parliament (see Table 1) we see that the process relatively quickly changed from reforming each standard separately to begin with, to, in a more inclusive way, reforming the two standards in parallel. What we also see is that this policy was reversed in 1981 where the focus again became on reforming only one of the varieties.

I will not comment on the different reforms in detail, only mention what I consider important in the present context. In the following I will explain how 
ideologies shifted during and after the most intensive language reform period, from the early twentieth century until after World War II and then explain the new development since the 1980s or 90 s and the consolidation of a new language planning strategy from the 21 st century onwards.

The bokmål reform of 1907 is important because it represents the first and very basic official shift from Danish to a Norwegian variety based on the oral language of the educated population in the south-eastern towns of Norway, particularly Kristiania/Oslo. From now on, it is no longer possible to call the Danish Language Norwegian, which actually often happened during the nineteenth century.

\section{The Samnorsk ideology and practice}

For our purpose, the most important reforms are those that took place in 1917, 1938 and 1959, particularly the first two (see Bull 2011: 434-440). They might all be interpreted as reforms with an aim to bring the two standards closer together. In that sense, we could call them "Samnorsk reforms". Even if the idea of a Samnorsk language had been under discussion since the 1880s, it is not until after 1907 that a practical policy pointing in that direction was possible. The way in which this policy was executed and operationalised kept developing through the three relevant reforms. The 1917 reform consisted of an obligatory and an optional part. The obligatory reform of bokmål (which was still called riksmål) was more or less a continuation of the 1907 reform. It was based on the pronunciation of the educated urban population in south-eastern Norway. The optional linguistic forms were much more radical and represented important morphological changes based on eastern Norwegian dialects with, for instance, a consistent three-gender nominal system. Language users, including school-children, could choose between e.g. hytta (f. def. sg.) or hytten (common gender def. sg.) - 'the cottage', diphthongs instead of monophthongs in words such as stein/sten - 'stone'. In these cases, the language users had an option; they could choose between variant grammatical systems and variant linguistic forms (Bull 2011: 435-436). This was indeed controversial. The socalled radical forms were a thorn in the eye to the more moderately inclined part of the population. The optional forms of nynorsk, on the other hand, represented a kind of simplification of the three-gender system, which meant a clear approximation or rapprochement to the optional bokmål three-gender system. Thus, the language users could choose between this more simplified three-gender system or the traditional more complicated one. In this way, the 1917 reform paved the way for those who on the one hand wanted to write a Norwegian standard language where the gap to the other variety of Norwegian was quite wide, or on the other hand, those who wanted the two standards to approach one another, and thus could choose grammatical forms or vocabulary that bridged the gap between the two standards. 
The 1938 reform made many of the optional forms from 1917 obligatory, thus paving the way further towards a future merging of the standards. A very important step in 1938 was to bring in a relatively strict and hierarchical two-level system to the two standards (Bull 2011:435-436). At one level, there were forms in both standards that were obligatory in all schoolbooks. That norm went under the name of schoolbook-forms or the school-book-norm. At the lower level, there was a wider option for the school children to use e.g. grammatical forms that coincided better with their own oral language, so-called sideforms. ${ }^{4}$ Within both levels of the hierarchy there was quite a wide range of variation, creating further options and more variant forms on both levels, in other words, very much variation. Actually, in hindsight this system was never a success, probably because it was too complex. Most of the schoolteachers were not able to help the children practice it; they themselves hardly understood the system or even knew about it. Still, this two-level system lasted for several decades; it was abolished in bokmål in 2005 and in nynorsk in 2012.

The 1959 reform was first and foremost a reform of the school book norm and was therefore called læreboknormalen - 'the school-book-norm' or 'the textbook-norm.' However, the norm applied also to the lower level and introduced some changes to the sideforms as well.

\section{$9 \quad$ Variation in standard written languages - a problem?}

Though the two-level system opened for even more variation than previously both in bokmål and nynorsk, the language planners still looked upon this high degree of linguistic variation as an unfortunate but necessary step towards a more uniform Norwegian norm or standard. At this time, no-one argued for linguistic variation per se. The ideal was still what Aasen had stated: Sprogformen bør kun være een (Venås 1996: 370); there should only be one linguistic form.

Interestingly, though the optional forms of the 1917 reform and the sideforms of the 1938 reform might function as an invitation to the language users, school children in particular, to write a Norwegian standard with a morphology and lexicon close to the users' own oral Norwegian, this was hardly ever used as a language planning argument. It was the Samnorsk strategy that had all the attention of the language planners (Bull 2011: 436-440.). The responsible language planners never talked about linguistic identity, linguistic authenticity, linguistic empowerment, linguistic emancipation, or linguistic human rights. There are no traces of this kind of

4 This might be exemplified by the language examples illustrating the two versions of the 1938-refrom in section 11. Only two tokens differ in these short texts: heime versus hjemme - 'at home' - and $n \varnothing g d$ versus $n \varnothing y d$ - 'satisfied'. Heime and $n \varnothing g d$ are the radical form, hjemme and nøyd the moderate ones deriving from Danish. 
arguing in the documents from the committee meetings or in the language debates in the media. The ideal was still to create one Norwegian written standard, and the great variation within the two standards was looked upon as an unfortunate but necessary step towards this end. Whether the future single standard should be like most European standards, without or with very little possibility for variation, was not discussed. Most of the language planners probably took it for granted that an ideal standard was a homogenous variety without much variation. However, this changed in the 1970s. I will return to this question in section 12.

\section{Reactions}

Needless to say, this continuous reformation of the standards did not take place peacefully and quietly. Each reform was met with severe and intensive criticism and debate. Nevertheless, after 1907, the initial debate blew itself out quickly, and the obligatory norm of the 1917 reform was relatively easily accepted, though the optional forms were met with quite strong criticism. The 1938 reform, however, created an uproar, but not until after World War II. This uproar was organised and carried out by the adherents of the conservative organisation Riksmålsforbundet, promoting their own riksmål, a privately standardised version of Danish-Norwegian. The uproar has been characterised as the strongest civil disobedience action in Norwegian history (Vinje 1978: 379f.). Parents were advised to "correct" the children's school books, and members of this organisation (Riksmålsforbundet) travelled the country and persuaded people to protest against the official language policy. School-books were even burnt, for instance in the city of Fredrikstad, where upper secondary students in the heat of the debate went to such drastic actions (op cit., Haugen 1966: 158-163, 177-187). The struggle was at its peak during the 1950s. It softened somewhat in the 1960s. Though the 1959 reform might be considered a continuation of the official Samnorsk-policy, and though Parliament had voted for it, the ruling Labour party had now got cold feet, and in 1964 the ministry appointed a committee with a mandate that - to put it in a popular way - was to create language peace (Bull 2011: 438-439.). The chair of the committee was Hans Vogt, a professor of linguistics and at that time the rector of the University of Oslo. In 1966, the committee presented a long row of proposals to soften the language struggle, among other things to create a new language organisation, Norsk språkråd, the Norwegian Language Council, which was established in 1972. (Bull 2011: 439-440.) 


\section{Examples}

Einar Haugen (1966: 275-280) illustrates the development of standard riksmål/ bokmål between 1900 and 1962 with six different versions of the folktale "Mannen som skulle stelle heime" - "The husband who was to do the housework"- and adds one nynorsk version. The same examples can also be found in Torp \& Vikør (2003: 252 255). I will quote the first few lines of Haugen's different versions, just to illustrate the linguistic variation within the official norms. Version 1 is the original Danish version, though the style and also the vocabulary are more Norwegian than Danish. Version 2 to 5 are all Norwegianised according to the different bokmål reforms, while version 6 reflects riksmål from 1962, a language form without official status, but deliberately named riksmål and used by Riksmålsforbundet. Version 7 is the only nynorsk example.

(1) Version from 1899, primarily Danish Manden som skulde stelle hjemme

Det var engang en Mand som var saa grætten og vild, og aldrig syntes han at Konen gjorde Nok i Huset. Saa kom han hjem en Kveld i Slaattaannen, og gren og skjændte og bandte, saa det lyste om ham.

“Kjære Vene, vær ikke så vond, Far", sagde Kjærringen, "i Morgen skal vi bytte Arbeide: jeg skal gaa ud med Slaattekarlene og slaa, saa kan du stelle hjemme." Ja, det syntes Manden godt om, og det vilde han gjerne.

(2) Version in 1911/1907 standard with some older forms (italicized)

\section{Manden som skulde stelle hjemme}

Det var en gang en mand som var saa grætten og vild, og aldrig syntes han at konen gjorde nok i huset. Saa kom han hjem en kveld i slaattonnen og gren og skjeldte og bandte, saa det lyste om ham.

"Kjære vene, vær ikke saa vond, far", sa kjærringen, "i morgen skal vi bytte arbeide: jeg gaar med slaattekarene, saa kan du stelle hjemme."

Ja, det var manden vel nøgd med, og det vilde han gjerne.

(3) Version in 1936/1917 standard

\section{Mannen som skulde stelle hjemme}

Det var en gang en mann som var så gretten og vill, og aldri syntes han at kjerringa gjorde nok i huset. Så kom han hjem en kveld i Slåttonna og grein og bante så det lyste om ham.

"Kjære vene, vær ikke så vond, far," sa kjerringa; "i morgen skal vi bytte arbeid: jeg skal gå med slåttekarene, så kan du stelle hjemme."

Ja, det var mannen vel nøgd med, og det vilde han gjerne.

(4) Version in 1940/1938 standard with radical forms (italicized)

\section{Mannen som skulle stelle heime}

Det var en gang en mann som var så gretten og vill, og aldri syntes han at kjerringa gjorde nok i huset. Så kom han heim en kveld i slåttonna og grein og bante så det lyste om han. 
"Kjære vene, vær ikke så vond, far," sa kjerringa; i morgen skal vi bytte arbeid: jeg skal gå med slåttekarene; så kan du stelle heime."

Ja, det var mannen vel nøgd med, og det ville han gjerne.

(5) Version in 1957/1938 standard, traditional forms (italicized)

Mannen som skulle stelle hjemme.

Det var en gang en mann som var så gretten og vill, og aldri syntes han at kjerringa gjorde nok i huset. Så kom han hjem en kveld i slåttonna og gren og bante så det lyste om ham

"Kjære vene, vær ikke så vond, far," sa kjerringa; i morgen skal vi bytte arbeid: jeg skal gå med slåttekarene; så kan du stelle hjemme."

Ja, det var mannen vel nøyd med, og det ville han gjerne.

(6) Version from 1962. Traditional riksmål forms (italicized)

Mannen som skulle stelle hjemme

Det var engang en mann som var så gretten og vill, og aldri syntes han at konen gjorde nok i huset. Så kom han hjem en kveld i slåttonnen og gren og skjennet og bannet så det lyste om ham.

"Kjære vene, vær ikke så vond, far," sa kjerringen;"imorgen skal vi bytte arbeide: jeg skal gå ut med slåttekarene og slå, så kan du stelle hjemme."

Ja, det syntes mannen godt om, og det ville han gjerne.

(7) Version 7: 1960. 1938 standard, moderate nynorsk

Mannen som skulle stella heime

Det var ein gong ein mann som var så gretten og vill, og aldri tykte han at kjerringa gjorde nok i huset. Så kom han heim ein kveld i slått-onna og grein og skjelte.

"Kjære vene, ver ikkje vond, far," sa kjerringa;"i morgon skal vi byta arbeid; eg skal gå ut med slåttekarane, så kan du stella heime."

Ja, det var mannen vel nøgd med, og det ville han gjerne.

Given that the example is a folktale the syntax in all examples is very oral-like. For the complete example texts the reader is referred to either Haugen 1966 or Torp \& Vikør 2003.

\section{Rethinking and reorientation}

In Norway, as in other parts of the western world, the late sixties and early seventies represented a radicalisation within the political landscape. Young people took to the streets, students protested against authoritarian educational systems, etc. The power structures of society were criticised and debated. As a consequence of this rethinking and reorientation, the relationship between language and power was high on the agenda. This time is also, as we know, the breakthrough of sociolinguistics as a linguistic discipline. 
This means that a rethinking about the issue of norms and standards also took place. In Norway, many of us began to argue that variation within the written standard might be an advantage, not only a challenge to be met with on the way to the - one - Norwegian standard in the future. A standard written language that allows for variation might meet the demands of particularly children who learn to read and write and help them recognise their own oral language in the written form. Moreover, it was considered to be in accordance with democratic principles that a written language should encompass linguistic material from not only one oral variety. Particularly young (socio-)linguists started to argue along these lines, emphasizing that the Norwegian system with this high level of variation in the standards, was far from a disadvantage, but rather the opposite. We should also bear in mind that since 1878 the home language (i.e. the dialects) of the school-children has had legal protection in Norway. And there is no official oral language standardisation in the country (e.g. Jahr 1984, 1989). To sum up this part, key concepts in the reorientation process were: empowerment, language and identity, linguistic authenticity, linguistic democracy, linguistic emancipation and the like.

One might ask whether this new orientation had any consequences for the actual language planning in Norway. The answer to this question is: yes and no. Yes, in the sense that the regular language planning activity that took place in the Language Council to a certain degree was influenced by this ideology. So, when the council from time to time discussed and decided on issues concerning standardisation, the varied pronunciation and existing forms in different Norwegian dialects were considered relevant criteria for what decisions to take.

\section{A farewell to samnorsk}

At the same time a movement away from the samnorsk ideology was clearly under way. Perhaps the most important proposal by the Vogt-committee ("the language peace committee") was to revise the bokmål norm, and that meant a revision away from samnorsk. And then, in 1981, a new bokmål reform was approved by Parliament (Bull 2011: 438-441). Now, a lot of conservative riksmål forms that had been excluded from the norm in 1938 and 1959 were again part of the norm.

The language planning development during the last decades of the twentieth century and until today can be interpreted as a gradual replacement of the samnorsk ideology by a new form of biliteracy ideology. The two-level system of the standards has now been removed, in bokmål in 2005, in nynorsk in 2012. This change was strongly influenced and encouraged - almost dictated, I would say - by the Ministry of Church and Culture. The new policy is quite clearly stated: the two varieties, bokmål and nynorsk, are to be considered separate language forms that are 
supposed to develop as individual, discrete and autonomous idioms on their own terms (Bull 2011: 440-443).

\section{The present situation}

So, how is the present situation to be described in an adequate way? Are we now starting from scratch, that is, back to the situation of 1885 when Parliament decided to place two written varieties on an equal footing? In a way we are, except for the fact that compared to the 1885 situation each of the two languages is a fully developed written medium, with relatively long histories as written languages. And importantly, the long period of samnorsk policy was also a period of language contact. The two Norwegian written standards are now much closer to one another than at the starting point, and both are much less archaic.

Given that the Norwegian standardisation history is quite unique, it is understandable that both the national and international public have had different reactions to it, both positive and negative. The specific Norwegian language situation has attracted the interest of quite a few linguists from outside Norway, who for the most part have looked upon the situation in a favourable way. The popular view, however, does not seem to be that positive. A repeated complaint, both from Norwegians and foreigners, argues that all this linguistic variation, both in the oral and written Norwegian varieties, makes the language hard to learn for foreigners. Nevertheless, the truth or falsity of this claim does not depend on popular opinion; it must be documented. Some research, which to my knowledge is the only existing documentation, actually points in the opposite direction. Since the Scandinavian languages are considered mutually comprehensible, there have been some researchers who have been interested in finding out and comparing to which extent Danes, Swedes and Norwegians understand one another's national languages. All research results known to me (e.g. Haugen 1972, Maurud 1976, Delsing \& LundinÅkesson 2005) point to the Norwegians as winners of this competition. Perhaps the most interesting and rather surprising findings are represented by the results of Delsing's and Lundin-Åkesson's 2005 investigation, where second-language users of the Scandinavian languages also took part as informants. The second-language users of Norwegian actually scored higher when it came to understanding the neighbouring languages compared to not only second language users of Danish and Swedish, but also compared to native speakers of these two languages. It is not unreasonable to assume that the main reason for this is the fact that Norwegian mother tongue users and also users of Norwegian as a second language are much more exposed to and therefore used to linguistic variation. Given that we all hear different Norwegian dialects all the time and that the two written standards still consist of quite a lot of parallel forms, learning to cope with linguistic variation is 
unavoidable. Adding Swedish and Danish to this variation does not represent a totally new situation for Norwegian speakers.

In 2007, The Labour Party government (Ministry of Church and Culture) presented a so-called White Paper to Parliament (St. meld. nr. 35). This is in fact the latest public document in Norway describing the linguistic situation of the country from the political authorities' point of view. The document abounds with interesting formulations. Among other things, it says that the foremost aim of Norwegian language policy is based on the recognition that Norwegian is separated into two written languages. Another formulation: "Everyone has linguistic rights, the right to acquire and develop the Norwegian language, bokmål and nynorsk" (my translation). Somehow, the Norwegian language manages to be one and two languages at the same time. To put it very directly, all that is said in this very important White Paper about the "new" language policy and the outcome of that, gives associations to magic formulas: we have one national language, and (or but) we have two! This is all but clear and straightforward. Though the White Paper was sent to Parliament more than ten years ago it has never been seriously discussed in a political context. ${ }^{5}$ So far, very little has come out of it, except for the fact that the official status is that we have two separate standards, but one Norwegian language.

\section{Summary and conclusion}

In the present paper, the readers have been taken on a language planning journey in Norway, starting in 1814, and ending -, ending firmly in a question mark, or what? I started by stating that during this long period of language planning, much of what was planned, was not accomplished, and what was accomplished was not planned. Firstly, the language planners wanted to replace Danish by Norwegian, meaning one Norwegian written standard. What was accomplished was two Norwegian standards. The plan was - with the help of corpus planning - gradually to merge the two standards into one common language, Samnorsk. What was accomplished was two standards with a high level of internal optionality and variation. The next and last step was a shift away from the Samnorsk ideology back to official biliteracy with a reduced level of variation, but still quite a lot, compared to other written languages. However, the bilingual/biliteracy policy is partly hidden in the rhetoric used by the authorities. Does Norway have one or two languages? What the White Paper says is that there is one Norwegian language, but two. It remains hard to understand why it is so difficult to state that the country has shifted from a monolingual or monoliteracy policy to a bilingual/biliteracy policy. 


\section{References}

Bandle, O., K. Braunmüller, E. Jahr, A. Karker, H-P. Naumann, U. Teleman, L. Elmevik \& G. Widmark (eds) 2002. The Nordic languages. An international handbook of the history of the North Germanic languages. Vol. I. Berlin: Mouton de Gruyter.

Bandle, O., K. Braunmüller, E. Jahr, A. Karker, H-P. Naumann, U. Teleman, L. Elmevik \& G. Widmark (eds) 2004. The Nordic languages. An international handbook of the history of the North Germanic languages. Vol. II. Berlin: Mouton de Gruyter.

Bull, T. 1987. 1885 enda ein gong. Maal og Minne, 1-4, 98-136.

Bull, T. 2011. Samnorsk. In J. Fishman \& O. Garcia (eds) Handbook of language and ethnic identity 2. The success-failure continuum in language and ethnic-identity efforts. New York: Oxford University Press, 432-444.

Bull, T. 2015. Grunnloven og språket. In T-H. Allern \& E. Niemi (eds) Nord-Norge og 1814 - med eller utenfor? Stamsund: Orkana Forlag, 285-299.

Bull, T. 2018 (ed.). Norsk språkhistorie III. Ideologi. Oslo: Novus.

Delsing, L. \& K. Lundin-Åkesson 2005. Håller språket i hop i Norden? En forskningsrapport om ungdomars förståelse av dansk, svenska och norska. Københvn: Tema Nord.

Dyrvik, S. 1998. Danmark-Norge 1380-1814, Vol. III: Truede tvillingriker 1648-1720. Oslo: Universitetsforlaget.

Elgvin, J. 1969a. Stortinget og sprogsagen. Ordet, 4, 15-170.

Elgvin, J. 1969b. Politikk, taktikk og realiteter i Stortinget 1885. Ordet, 10, 407-421.

Gimnes, S. 2002. Nordic language history and literary history III: Norway. In O. Bandle, K. Braunmüller, E. Jahr, A. Karker, H-P. Naumann, U. Teleman, L. Elmevik \& G. Widmark (eds) 2002. The Nordic languages. An international handbook of the history of the North Germanic languages. Vol. I. Berlin: Mouton de Gruyter.

Habermas, J. 1962. Strukturwandel der Öffentlichkeit. Untersuchungen zu einer Kategorie der bürgerlichen Gesellschaft (habil.). Frankfurt am Main: Suhrkamp.

Haugen, E. 1966. Riksspråk og folkemål- Norsk språkpolitikk i det 20. århundre. Oslo: Universitetsforlaget.

Haugen, E. 1972. Semicommunication: The language gap in Scandinavian. In E. Firchow (ed.) Studies by Einar Haugen: Presented on the Occasion of his 65 ${ }^{\text {th }}$ Birthday, April 19, 1971. Janua Linguarum. Series Maior 49. Berlin: Mouton de Gruyter, 479-495.

Hoel, O. 2018. Unionstida med Sverige (1814-1905). In A. Nesse (ed.) Norsk språkhistorie IV. Tidslinjer. Oslo: Novus, 425-502.

Indrebø, G. 1951. Norsk målsoga. Bergen: John Griegs boktrykkeri.

Jahr, E. 1984. Talemålet i skolen. Oslo: Novus.

Jahr, E. \& I. Schanche 1988: Jamstellingsvedtaket i 1885 - forstår vi det nå? Norsk lingvistisk tidsskrift, 1/2, 139-150.

Jahr, E. 1989. Utsyn over norsk språkhistorie etter 1814. Oslo: Novus.

Johnsen, E. 2005. Unorsk og norsk: Knud Knudsen. En beretning om bokmålets far. Tvedestrand: Bokbyen forlag.

Maurud, Ø. 1976. Nabospråksforståelse i Skandinavia. Stockholm: Nordiska rådet.

Nesse, A. (ed.) 2018. Norsk språkhistorie IV. Tidslinjer. Oslo: Novus.

Nesse, A. \& A. Torp 2018. Dansketiden (1536-1814). In A. Nesse (ed.) Norsk språkhistorie IV. Tidslinjer. Oslo: Novus, 357-424.

Rian, Ø. 1997. Danmark-Norge, Vol. II: Den aristokratiske fyrstestaten 1536-1648. Oslo: Universitetsforlaget.

Sandøy, H. \& A. Nesse (eds.) 2016-2018. Norsk språkhistorie vol. I-IV. Vol I: H. Sandøy (ed.): Mønster 2016. Vol II: B. Mæhlum (ed.): Praksis 2018. Vol. III: T. Bull (ed.): Ideologi 2018. Vol. IV: A. Nesse: Tidslinjer 2018. Oslo: Novus. 
St. meld. 35. 2007-2008. Mål og Ein heilskapleg norsk språkpolitikk. White Paper presented to Parliament by Governmet of Norway, Ministry of Church and Culture. https://www. regjeringen.no/no/dokumenter/stmeld-nr-35-2007-2008-/id519923/sec1 [accessed 24 June 2018]

Torp, A. \& L. Vikør 2003, 3rd edition. Hovuddrag i norsk språkhistorie. Oslo: Ad Notam Gyldendal.

Venås, K. 1996. Då tida var fullkomen. Ivar Aasen. Oslo: Novus.

Vikør, L. 2018. Jamstellingsvedtaket i 1885. Ein replikk. (1990). In L. Vikør (ed.) Nynorske nedslag. Ei artikkelsamling. Oslo: Novus, 119-130.

Vikør L. 2018. Standardspråk og normering. In T. Bull (ed.) Norsk språkhistorie III. Ideologi. Oslo: Novus, 327-419.

Vinje, F-E. 1978. Et språk i utvikling. Oslo: Aschehoug. 